\title{
BARRIERS FOR ECO-INNOVATIONS: A CASE STUDY OF A SMALL FIRM IN POLAND'
}

\author{
Andrzej H. JASIŃSKI*, Filip TUŻNIK**
}

*School of Management, University of Warsaw, Warsaw, Poland, e-mail: ajasinski@wz.uw.edu.pl

**PhD student in the School of Management and a manager in Tuzal Ltd., Warsaw, Poland, e-mail: ftuznik@wz.uw.edu.pl

\begin{abstract}
This paper is mainly based on a case study of Tuzal Ltd. - a small firm acting in the eco-innovation market in Poland. The main aim of the paper is to analyze main barriers which are being met by enterprises, especially small firms, acting in the eco-innovation market. The following barriers are analysed: problems in convincing customers to innovative solutions; a specific nature of cooperation with local administration units; continuous changes in legal regulations; an increasing market competition; a lack of funds for marketing; a generation gap and a retirement age of the company's owner.
\end{abstract}

Key words: eco-innovation, environmental technologies, small firms.

\section{$1 \quad$ Introduction}

Taking decisions in a flat decision problem (or in other Recently, we can observe a growing role of eco-innovations, both as a research subject and as a part of business as well. However, managers, especially in small and medium-sized enterprises (SMEs), must be fully aware of numerous barriers in the eco-innovation market and should know how to overcome them.

The paper's aim is to analyse main barriers which are being met by enterprises, especially small firms, acting in the eco-innovation market. The paper is mainly based on a case study of Tuzal Ltd. - a small firm acting in the eco-innovation market in Poland.

We shall try to show that a small firm which intends to launch eco-innovations must run a skilful, balanced 'game' between factors favourable and non-favourable to such activities.

\section{A short literature survey}

A scientific literature on eco-innovations is already quite rich $[5,7,11]$. A big emphasis on eco-innovation, in the context of the sustainable development, is being put by the European Council within such documents as Europe 2020, Innovation Union and Eco-innovation Action Plan (EcoAP) or the earlier Eco-Management and Audit Scheme (EMAS) of 2001.

One of three main goals of 'Europe 2020' strategy is building a greener society. An issue of eco-innovation is mentioned in several places in Innovation Union, e.g. in

\footnotetext{
${ }^{1}$ This is a revised version of the paper presented at the CAMOT
} 2012 Conference, Shanghai, 29-31 October 2012.
15 th and 18th action points. EcoAP, accepted just recently, directly results from Innovation Union - one of seven EU flagship initiatives.

In the context of eco-innovations or, in other words, new environmental technologies, a crucial role of a social awareness is being stressed in numerous studies - both in relation to consumers' behaviour as well as to firms' behaviour. The former relates to a so-called new, ecological consumer/consumption $[2,9]$ while the latter is a part of corporate social responsibility (CSR) $[1,4,12]$.

Also, an issue of barriers for innovations is widely developed in literature, including the barriers/obstacles for innovation activities in SMEs [8, 10]. In Poland, for instance, SMEs complain about the cooperation, or a lack of it, with research organisations, banks, financial investors, other business environment institutions and local governments [6]. Frankly speaking, similar observations happen in the European Union as a whole. SMEs often struggle to convince financial institutions to invest in them or lend to them; they require a business-friendly environment to flourish.

According to Wrzesiewski and Miler [13], the Polish ecoinnovation market/sector is in an initial phase of development; a relatively big role is being played by imported technologies; producers of environmental technologies have a weaker market position in comparison with their distributors. Only 26 Polish companies were registered within EMAS in 2010 [3].

There are numerous reasons for such a state of affairs both on the demand side and on the supply side.

Too small the demand for eco-innovation is the result, among other things, of:

- toohighthe prices ofecological products, e.g. ofeco-food,

- still low pro-ecological awareness among consumers, 
- a weakly expanded sustainable development regime, ${ }^{2}$

- high costs of exploitation of environment-friendly devices.

Among the reasons for too small the supply of eco-innovations are:

- a very small interest in EMAS among enterprises,

- various difficulties in the implementation of ISO 14001,

- insufficiently popularised CSR approach in industry,

- long periods of waiting for new environmental technologies being worked out in the Polish R\&D sector.

However, a quick step forward has taken place in this field recently. Namely, within The Operational Programme 'Infrastructure and Environment', financed by EU Structural Funds and Coherence Fund, there is Action 4.3: Support for firms implementing the best available technologies (BATs). The enterprises introducing eco-innovations may gain a financial support from this source, although ecoinnovation is not - unfortunately - a separate category entitled for grants.

According to the report based on a questionnaire research among 278 enterprises operating in the Polish eco-innovation market, numerous external (outside the firms) and internal (inside the firms) barriers were identified [13].

Three main external barriers mentioned by the respondents are:

- a growing competition in the sector, often a dishonest price competition,

- a difficult access to financial capital (tough bank credit conditions),

- difficulties in getting permits from local governments for installation of environmental devices.

Three main internal barriers are as follows:

- financial constraints, i.e. a lack of own funds,

- too weakly developed distribution channels,

- difficulties in finding demands for their products.

\section{Tuzal Ltd.: A case study}

One of firms operating in the eco-market in Poland is Tuzal Ltd. This is a small, family enterprise established in Warsaw in 1990. The firm employs three people permanently but used to employ, if needed, bigger groups of workers, often exceeding 20 people. Tuzal plays a double role of producer and distributor of environmental

\footnotetext{
2 Until recently, a coal being extracted in the country was called 'a black gold'.
}

technologies, such as EcoDrain, ORTWE, FKJA/LAFT (see below). The firm's main market activities in the last decade and now have been as follows:

- to produce EcoDrain devices with Aikaterisil fillings for cleaning storm wastewater,

- to operate as the agent in selection of environmental protection technologies,

- to offer services for old chemical reagents, waste and hazardous solutions containing heavy metals and petroleum derivatives,

- to liquidate old, closed contaminated chemical facilities,

- to coordinate an international project SOILSTABSORBENT within the program EUREKA that resulted in elaboration of the ORTWED method sludge treatment plant, and

- to exclusively distribute the FKJA/LAFT method used to neutralisation of dilutions, wastewater and wastes from metal surface treatment, especially wastes from galvanisation processes.

The SOILSTABSORBENT project was established in 2002 within the EUREKA program (Project E!2695) as a result of studies of Polish-Danish research and development group. The aim of the project was to verify whether the oiled sludge, containing petroleum derivatives could be used as a stabilisation factor in the road construction process. To achieve the goal, the sludge was mixed with a highly reactive lime that came together with the water contained in the sludge in an exothermic reaction, so the dry hydrophobic granulate was obtained. The research on an environmental impact of the process were run in The Warsaw University of Technology and in The Road and Bridge Research Institute in Warsaw where the granulate was studied as a potential road stabilisation factor, and continued in The Chemistry, Oil and Coal Institute at The Wroclaw University of Technology where the granulate was examined as a toxic-gases absorber. There were $400,000 \mathrm{Mg}$ petroleum derivative waste neutralised in the ORLEN Group facilities in Plock in 2001-2004, as a part of the project.

The next technology is the EcoDrain ${ }^{\mathrm{TM}}$ system with AikaterisilTM fillings. It is used as the rainwater treatment plant that is to be put directly into drains situated on roads, car parks, petrol stations and everywhere else where a problem of rainwater treatment occurs. The technology originates from Sweden, and TUZAL has an exclusive right for introducing it into the Polish market. The first such units were installed in 2003 in Plock. What is innovative in this technology is that it neutralises the wastewater at the very beginning of the pipeline system, in comparison 
to the classical methods, set on cleaning at the end of the drainage system. Moreover, because EcoDrain system is not connected to the ground, it does not need a building permit.

Tuzal has introduced several innovative modifications to the system of sterilisation of sludge using highly active lime. As a result, the ORTWED method was applied as the sludge treatment solution for municipal waste water treatment plants. The point of the process was to transform the sludge into a full-value fertiliser. A first such installation was erected in Glogow Malopolski, Poland in 2010. The idea of introducing this product into the market has arisen in the company due to the difficulties that municipalities had with treating sludge, especially after Poland was forced to meet the European Union requirements. Moreover, now we know that the method is suitable for many applications, such as municipal water treatment plants, biogas plants, food, herbal or animal production facilities.

TUZAL Ltd. is also the only representative/distributor of the FKJA/LAFT method both in Poland and abroad. This technology enables heavy and noble metals' recovery from wastewater in metal surface treatment facilities with simultaneous neutralisation of hazardous, toxic and dangerous chemical compounds like cyanides barium or arsenic derivatives. The technology has more than twenty Polish and global patents and utility designs. The major author who is also a founder of TUZAL Ltd. was several times awarded worldwide for this method which was applied more than 250 times all over the world.

At the moment, the company's strategy is to work hard on innovative technologies. It works on environmentally friendly, especially eco-innovative technologies. We believe that successful implementation of these technologies can increase the firm's income and competitiveness in the market. Moreover, Tuzal's goal is to come to an end with projects opened during last three years and, of course, to set up some new of them. There is a plan to employ young, energetic people in order to increase marketing activity.

Profits generated by Tuzal in 2007-2011 were: $\$ 24,300$ in 2007; $\$ 16,000$ in 2008; $\$ 13,200$ in 2009; and $\$ 1200$ in 2011 (in 2010, there was a small net loss). Provisional data for 2012 are very promising again.

In our opinion there were several reasons of this decreasing profit tendency. First of all, it is due to the international economic crisis that had an influence on lesser purchases, and extended period from the first contact to accomplishment of the project with a particular customer. The another reason was a significant increase in costs, including those borne on marketing that are due to a lengthening of the customer search process and to local administration decision processes, related with the lack of finance for innovation. The other factor that influenced the company's financial situation worsening was a termination, in 2010 , of cooperation with a long-term customer for whom the company offered a big part of its works.

Nevertheless, the main sources of TUZAL Ltd. successes seem to be as follows:

- a belief in management capabilities to run the business and in the utility of technologies proposed,

- wide connections struck up by company employees as well with representatives of Polish and global companies as with local administration all over Poland,

- a continuous search of innovations and capability for selection of the most original and useful ideas,

- a broad professional experience and a specialist knowledge of the company's founder, Franciszek Tużnik, who has entirely used the wisdom gained during his university studies and work on the Ph.D. thesis,

- a persistence in aspiration to set up ambitious goals for the firm,

- a flexibility in searching of market opportunities and commissions as well as possession of wide range of technologies.

\section{Barriers for eco-innovations}

As many small enterprises in Poland, Tuzal encounters various barriers connected with market application of innovative technologies. They are analyzed below.

\subsection{Problems in convincing customers to innovative solutions}

Several generations of Polish people were downgraded by socialism and communism in innovative thinking. Instead of activity development, the society was learnt how to adopt and duplicate solutions invented somewhere else. TUZAL Ltd. finds this problem as the main barrier in reception of innovative technologies among potential customers in Poland who are much more distant to them than other European nations. When one chooses innovative solution he/she has to change his/her way of thinking or even entire approach to the problem. This lack of possibilities to directly compare innovation to something already known makes a big barrier.

Traditional marketing efforts, like advertisements in specialist periodicals and an attendance at fairs and confer- 
ences, could be not enough to persuade customers to an innovative solution. To overcome this barrier TUZAL tries to introduce semi-technical installations that could constitute experimental models, useful for demonstration of the proposed solutions among customers.

A presence of the mental barrier is not optimistic. It is the fear of progression that made the Polish saying 'it will be somehow' very popular. The saying does not originate from nowhere. It is socialism that made our society so non-innovative, and that system is first to be blamed for such deprived reception of innovative solutions and irrational trust in old, often invalid technologies. That is also why many creative Polish people decide to emigrate to Western countries where they expect to successfully create and produce innovative solutions.

\subsection{A specific nature of cooperation with local ad- ministration units}

TUZAL Ltd. has broad business contacts with local administration units. Unfortunately, people working in these units often are not well prepared to their work, do not understand or even do not want to understand economic, ecological and social effects of using innovative solutions. This situation is caused due to the clerks' connections with certain political options or to an influence by strong lobby groups.

Moreover, in almost every single public tender the most important criterion is the lowest offered price. In such situation, many innovative solutions with higher investment costs are rejected, even if their further exploitation costs are much lower. That is why innovative products are not launched into the market while old, defective solutions are being installed. Such faulty technologies are very easy to be found in Poland where roads, motorways, municipal facilities are just at the beginning of the list.

Another problem is the social responsibility of the people employed in local administration units. If the proposed technology fails they are the first to be blamed for that. TUZAL Ltd. has several times faced a situation where the clerks were convinced to the offered method but they were afraid of introducing it. Also, a lack of appropriate funds for introduction of innovative technologies and long-lasting decision-making processes potentially make a serious problem in implementation of innovative methods.

To avoid these barriers, TUZAL tries to advertise and talk about innovative technologies at every level of the local or regional administration. Such debates, open for everyone involved in the decision-making process, can reduce the barriers among representatives of the unit and help convince them to a given solution.

\subsection{Continuous changes in legal regulations}

The inconstancy and incoherence of Polish legislation is a big problem in business activity. Most of all it is caused by clerks and ignorance of legislators as well as of a significant influence by lobby groups. These aspects also made it very hard to introduce innovative solutions. It is really not an accident that Poland is far away in business-friendly countries ranking.

In the conditions mentioned above, it is difficult to prepare long-term business plans and then to accomplish them on time and in accordance with already made decisions. Moreover, this situation requires constant actualisation of legal wisdom, often hard to be understood.

Another problem is followed by an inconsistency and misinterpretation of the legal acts. Whereas this practice causes incompatibility of legal forms and settlements which are obligatory for companies to prepare on a regular basis. This misinterpretation can even lead to obstruction or even elimination of smallest enterprises.

Moreover, more complicated, incoherent and ambiguous legal acts entail corruption, larceny and frauds. Together with the lack of responsibility for such delinquencies, many of those small enterprises decide to register abroad.

Although TUZAL Ltd. cannot do much about legislation, the company tries to fulfil its goals and even come up with new technological solutions. Several legal acts can intensify requirements amongst customers and so a chance occurs for the company to introduce innovations or achieve different marketing approach. Such situation requires an acquisition of constantly changing law.

\subsection{An increasing market competition}

In Poland, various market sectors have recently being taken over by several international corporations. Such market conditions are a real menace for small enterprises, like TUZAL. Many of those are forced to leave the market. Among others it often causes an activity obstruction or precludes the prevalence of their innovative solutions.

There are in fact two types of market competition from a view-point of small enterprises. One is a fair competition with other players from the same level (SMEs). The other type relates to a competition with the corporations that have a big financial and social power, making them able 
to play the market game on their own rules. This often leads to a closing of any chances for smaller companies to introduce their new products or methods of production. What is more depressing, corporations have a big influence on authorities and legislation, so this barrier will only be stronger in the future.

The second problem connected with an increasing market competition is the appearance of much more, then before, substitutes in the market then before that lowers a market value of TUZAL's products, even those innovative. It is said that a normal solution here is to patent innovative units. In fact, it does not always bring an expected effect. Potential costs and long-term period of compensation often makes it impossible for small enterprises to initiate such cases. What is here sad, but true, is that patenting does not always mean protecting.

Both barriers - connected with corporations and with substitutes - are a significant problems. It looks like that there is the only one solution in such situation, i.e. a constant work on innovations and searching of technologies abroad to introduce them in local markets. TUZAL has chosen this way.

At the end, it is important to suggest some legal solutions to the mentioned problem. There is no simple, long-term support program for innovative enterprises in Poland. There is also needed some kind of assistance in creating partnerships between enterprises and research institutes. This should intensify Polish innovation movement for sure.

\subsection{A lack of own funds for marketing}

An increasing competition needs a bigger money support for promotion of products. A lack of funds is not a prosaic problem here. In fact, many enterprises like TUZAL, know how it is difficult to sell a product without a good marketing or even a chance to be present in mass-media. But in fact very often it is simply impossible.

In result, a little money support for promotion lowers the chance to eventually sell an innovation. Again, this situation is good for corporations that quite often retake from small enterprises the most attractive ideas for little money and introduce them as their own ones. This problem affects not only small entrepreneurs but also diminishes national revenues.

A basic plan here is to assign money from other business fields to spend for marketing. Because this solution decreases funds for other purposes, TUZAL tries to maintain contacts with research institutes and takes part in scientific publications where the company can also advertise its products.

This practice is rather a defensive activity, resulting from a lack of other perspectives. Only if decision-makers understand that boosting native innovation program gives a chance to strengthen national economy, there will be a view of some significant changes. Only a real marketing support for innovative technologies can help in expansion of them both in Poland and all over the Europe.

\subsection{A generation gap and a retirement age of the company's owner}

As mentioned, TUZAL Ltd. is a family enterprise and all firm's shares belong to the same family. Everyone tries to invest much energy and wisdom to make the company develop and expand in the market. It is the company's founder contribution who gives his knowledge and a practical expertise. His son, a representative of the young generation, has an economic and marketing knowledge and helps achieve the firm's goals.

It is normal that people from different generations have separate points of view and concentrate on different, often contrary activities. That is also why they have their own visions of how to lead the company. Luckily, this barrier was minimised in TUZAL Ltd. Internal partners accept others drawbacks and know how to use each other's advantages. They also know they can rely on each another, no matter what will happen.

It looks like a mutual understanding, and so trust is the chance for such a family enterprise to achieve any success. Only then a generation gap can bear fruits and does not stop the company's development.

To sum up, a generation gap in the company can be an advantage and a help for young generation. Wisdom and experience of old generation, together with broad education of younger co-owners can provide a presence in the market or even a chance to develop further and keep introducing innovations faster and with more chance to success.

\section{Conclusions}

We have identified six following barriers for eco-innovations in small firms:

- problems in convincing customers to innovative solutions, 
- a specific nature of cooperation with local administration units,

- continuous changes in legal regulations,

- an increasing market competition,

- a lack of funds for marketing,

- a generation gap and a retirement age of the company's owner.

As seen, here there are barriers which:

- belong to both groups, i.e. external and internal ones,

- are typical barriers for technological innovation and those specific for eco-innovation,

- confirm at least some of the barriers mentioned at the beginning of this paper.

Legal and formal requirements, like obligation to present in national offices various certificates, permissions or to fill out not often necessary forms or reports, including those authenticated by a notary, have an influence on time, financial and tax commitments and lengthen technology implementation processes. This situation places Poland in the very far position on the list of business-activity supporting states and reduces operation opportunities for Polish companies. This fact has an influence on big number of bankruptcy among Polish micro-enterprises.

Having above in mind, one can come to the conclusion that all those barriers and requirements lead to economic slowdown that implies downward income tendencies in small enterprises like TUZAL Ltd. and influences economic slowdown on the macro-economic scale. In spite of all, Tuzal successfully tries to struggle with these adversities.

\section{$6 \quad$ References}

[7] Aras G. (ed.) - Corporate social responsibility in SMEs. SRRN, Leicaster, 2009.

[8] Castenow D. - Nowy konsument. PWE, Warszawa, 1993.

[9] Dąbrowska M. - Ekoinnowacje. PARP, Warszawa, 2010.

[10] EC Green Paper, Brussels. 2001.

[11] Freier I. - Environmental management from an ecological modernization and innovation perspective. Chemnitz University of Technology, Chemnitz, 2003.

[12] Jasiński A.H. - Innowacje i transfer techniki w procesie transformacji. Difin, Warszawa, 2006.

[13] Jones E. (ed.) - Managing creative eco-innovation [in] Journal of Sustainable Product Design, No 1, 2001.
[14] Jones M., Jain R. - Technology transfer for SMEs: Challenges and barriers [in] International Journal of Technology Transfer and Commercialization, No 1/2, 2002.

[15] Kiełczewski D. - Konsumpcja a perspektywy zrównoważonego rozwoju. Wydawnictwo Uniwersytetu w Białymstoku, Białystok, 2008.

[16] Oakey R. (ed.) - Management of innovation in hightechnology small firms. Pinter Publishers, London, 1998.

[17] Reid A., Miedziński M. - Eco-innovation: Final report for Sectoral Innovation Watch, EUROPE INNOVA, Brussels, 2008.

[18] Whitehouse L. - Corporate social responsibility, corporate citizenship and the global compact. SAGE Publications, London, 2003.

[19] Wrzesiewski \& Miler s.c. - Rynek polskich technologii środowiskowych, Warszawa, 2010. 